\title{
Xanthones Analysis and Antioxidant Activity Analysis (Applying ESR) of Six Different Maturity Levels of Mangosteen Rind Extract (Garcinia mangostana Linn.)
}

\author{
Marisca Evalina Gondokesumo ${ }^{1,2, *}$, Bambang Pardjianto ${ }^{3}$, Sutiman Bambang Sumitro ${ }^{4}$, Wahyu Widowati ${ }^{5}$, \\ Kusworini Handono ${ }^{6}$
}

Marisca Evalina Gondokesumo ${ }^{1,2, *}$, Bambang Pardjianto ${ }^{3}$, Sutiman Bambang Sumitro ${ }^{4}$, Wahyu Widowa$\mathrm{ti}^{5}{ }^{5}$ Kusworini Handono ${ }^{6}$

${ }^{1}$ Faculty of Medicine, Biomedical Sciences Doctoral Study Program, Brawijaya University, Malang, East Java, INDONESIA.

${ }^{2}$ Faculty of Pharmacy, University of Surabaya, Surabaya, East Java, INDONESIA.

${ }^{3}$ Department of Plastic Surgery, Saiful Anwar General Hospital, Faculty of Medicine, Brawijaya University, Malang, East Java, INDONESIA.

${ }^{4}$ Department of Biology, Faculty of Mathematics and Natural Sciences, Brawijaya University, Malang, East Java, INDONESIA.

${ }^{5}$ Faculty of Medicine, Maranatha University, Bandung, West Java, INDONESIA.

${ }^{6}$ Department of Clinical Pathology, Faculty of Medicine, Brawijaya University, Malang, East Java, INDONESIA.

\section{Correspondence}

Mrs. Marisca Evalina Gondokesumo

Faculty of Medicine, Biomedical Sciences Doctoral Study Program, Brawijaya University, Malang, East Java, INDONESIA.

Phone no : +6287851367988

E-mail: mariscaevalina@gmail.com

\section{History}

- Submission Date: 24-09-2018

- Review completed: 22-11-2018;

- Accepted Date: 07-12-2018.

DOI : 10.5530/pj.2019.11.56

Article Available online

http://www.phcogj.com/v11/i2

\section{Copyright}

(c) 2019 Phcog.Net. This is an openaccess article distributed under the terms of the Creative Commons Attribution 4.0 International license.

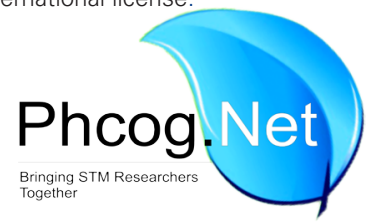

\begin{abstract}
Background: Mangosteen (Garcinia mangostana Linn.) is tropical fruit that known to contain bioactive compounds which has particular function as antioxidant, anti-inflammatory and antibacterial. Mangosteen rind extract is known to have high contents of xanthone compounds which have antioxidant and free radical scavenging activities. This study was done to determine the contents of xanthone derivatives using Liquid Chromatography Mass Spectrometry (LC-MS/MS) and antioxidant activity of six different maturity levels of mangosteen rind extract using Electron spin resonance (ESR). Method: Mangosteen was classified based on the maturity level by its visual characteristic and divided into six criteria of maturity. The mangosteen rinds were extracted through maceration and freeze drying method. Qualitative analysis of xanthone was obtained using LC-MS/MS. Antioxidant activity was determined using ESR spectrometer. To evaluate antioxidant activity, using 2,2-diphenyl-1-picrylhydrazyl (DPPH) was used as free radical scavenger method. Results: The LC-MS/MS analysis showed that the highest concentrations are filled by mangosteen rind with maturity level 6. Moreover, each maturity levels of mangosteen rind extract has different $g$ value compared to DPPH free radical. Different $g$ value indicated the different type of free radical and decreasing $g$ value indicated the declining intensity of free radical. The higher decreasing of $g$ value was mangosteen rind with maturity level 4, 5 and 6. Conclusion: Mangosteen rind extract contains xanthone and its derivatives and ESR analysis showed that different maturity levels on mangosteen rind has different antioxidant activity as indicated by declining free radical intensity. Key words: Antioxidant, Electron spin resonance (ESR), Free radical, Mangosteen rind extract, Xanthone Garcinia mangostana.
\end{abstract}

\section{INTRODUCTION}

Natural products and naturally derived antioxidants are more becoming popular in medical purpose. ${ }^{1}$ Mangosteen rind (Garcinia mangostana Linn.) has long been widely used in traditional medicines. ${ }^{2}$ Antioxidants properties in mangosteen rind are postulated for having important role to promote health benefits and prevent some diseases. ${ }^{3}$

Several antioxidants and bioactive compounds are found in mangosteen rind extract such as prenylated and oxygenated xanthones ${ }^{4}$ and xanthones..$^{5-7}$ Xanthones have an unique chemical structure which composed by tricyclic system $\left(\mathrm{C}_{6}-\mathrm{C}_{3}-\mathrm{C}_{6}\right)$. The most abundant xanthones in mangosteen rind are $\alpha$ - and $\gamma$-mangostin. ${ }^{6-8}$ Other xanthones in mangosteen pericarp include garcinones $\mathrm{C}, \mathrm{D}, 9,6$ 8-deoxygartanin, $\beta$-mangostin, garcinones $\mathrm{A}, \mathrm{B}$ and $\mathrm{E}$, mangostinone, 9-hydroxycalabaxanthone and isomangostin. ${ }^{9}$ Those compounds have been reported to have antioxidant activity, anti-pro- liferative, pro-apoptotic, anti-inflammatory, antiobesity, anti-carcinogenic and anti-microbial activities. ${ }^{10,3,6,7}$

Furthermore, total bioactive compound content and antioxidant activity were found to be different in various maturation stages of mangosteen rind. ${ }^{11,2}$ Recent study suggests that total phenolic contents were decreasing during the maturity stage of mangosteen rind. ${ }^{11}$ Kurniawati ${ }^{12}$ mentioned that the exploitation of xanthone in mangosteen as antioxidant has great prospect for phytopharmaca and food industries.

Therefore, it is important to study the content of various compounds and antioxidant activity in the different level maturity of mangosteen rind in Indonesia. The aim of this research was to obtain the extract of macerated xanthone compounds from mangosteen rind, such as garcinone E, gartanin,
Cite this article: Gondokesumo ME, Pardjianto B, Sumitro SB, Widowati W, Handono K. Xanthones Analysis and Antioxidant Activity Analysis (Applying ESR) of Six Different Maturity Levels of Mangosteen Rind Extract (Garcinia mangostana Linn.). Pharmacog J. 2019;11(2):369-73. 
$\gamma$-mangostin and smeathxanthone A as a standard using Liquid Chromatography Mass Spectrometry (LC-MS/MS).

In addition, antioxidant activity of each level maturity of mangosteen rind was also assessed by Electron spin resonance (ESR) and 2,2-diphenyl1-picrylhydrazyl (DPPH) was used as free radical standard. ESR has been known as one of the best procedure for free radicals detection of and has been used to investigate antioxidant properties in compounds. ${ }^{13}$ The approximation of antioxidant properties in drugs or food may also be applicable using this technique. ${ }^{14}$ The Electron paramagnetic resonance (EPR) spin trapping method involves trapping of reactive shortlived free radicals by a diamagnetic EPR silent compound (spin trap) via addition to a spin trap double bond to produce a more stable radical product (spin adduct). ${ }^{15}$

\section{MATERIALS AND METHODS}

\section{Classification of mangosteen}

Mangosteen was classified based on the maturity level by its visual characteristic and divided into six criteria of maturity, as shown in Table $1 .{ }^{16-18}$

\section{Plant materials and preparation}

Mangosteen rind (G. mangostana Linn.) was obtained from Bandung, West Java based on harvesting age (coded as 1-6). The plants were identified by the herbarium staff of the Department of Biology, School of Life Sciences and Technology, Bandung Institute of Technology, Bandung, West Java, Indonesia. The rinds were collected, kept in drier tunnel device, chopped, milled and extracted with maceration method using ethanol $96 \%$ as the solvent. The simplicia powder of mangosteen rind (700 g) was immersed in ethanol $96 \%$ with ratio $1: 5$ and stirred every $3 \mathrm{~h}$ for 5 days. The solvent was then evaporated to obtain the extract. ${ }^{4,6,10}$ Furthermore, the mangosteen rind extract was continued to freeze dry using freeze dryer which resulted in mangosteen rind extract (MRE) with six maturity level and were stored in $-20^{\circ} \mathrm{C}$ temperature. ${ }^{4,6,10}$

\section{Quantitative analysis of liquid chromatography mass spectrometry (LC-MS/MS) profiling}

The quantification of MRE with six maturity levels was conducted using the standard Garcinone E (ChemFaces, CFN92697), gartanin (ChemFaces, CFN98428), $\gamma$-mangostin (ChemFaces, CFN98396) and smeathxanthone (ChemFaces, CFN97260). Quantification of six MRE were performed with Liquid Chromatography Mass Spectrometry (LC-MS/MS) (Accella 1250, Thermo Scientific). Each sample was dissolved in $1 \mathrm{~mL}$ methanol gradient grade and filtered through $0.2 \mu \mathrm{m}$ syringe. Mobile phase using formic acid $0.1 \%$ was used. MS/MS Triple Q (quadrupole) mass spectrophotometer TSQ Quantum Access MAX Triple Quadrupole (Thermo Scientific) Electrospray Ionization (ESI) (voltage $3 \mathrm{kV}$; evaporation temperature $250^{\circ} \mathrm{C}$; capilary temperature $300{ }^{\circ} \mathrm{C}$; nitrogen $40 \mathrm{psi}$ and Aux 10 psi with argon gas) be used to measure the absorbance and controlled by software TSQ Tune operated with positive polarity. ${ }^{6,19,20}$

\section{Electrone spin resonance (ESR) analysis}

ESR spectrometer was used to evaluate the absorption of electromagnetic radiation. Determination of antioxidant capacity was performed by the EPR spectroscopy. Antioxidant rate was determined using the method described previously. Bruker EMX EPR spectrometer (Bruker-Biospin, Germany) was used to obtain electron paramagnetic resonance spectra, operating at the X-band frequency at room temperature $\left(24^{\circ} \mathrm{C}\right)$. The specific instrument parameters were: Central field $335 \mathrm{mT}$, Sweep width $15 \mathrm{mT}$, Field modulation width $(\mathrm{FMW})=0,5 \times 1$, Receiver gain $=100 \mathrm{G}$, Microwave power $=20.12 \mathrm{~mW}$, Frequency $9.27 \mathrm{GHz} .^{21,22}$

\section{RESULTS}

\section{Xanthones analysis in mangosteen rind extract (MRE)}

Figure 1, shows the presence of four standard compounds including $\gamma$-mangostin, gartanin, smeathxanthone and garcinone-E in the extract as indicated by the retention time. The quantitative analysis was then measured (Table 1), it shows that MRE with six maturity level contains $\gamma$-mangostin, garcinone- $\mathrm{E}$, gartanin and smeathxanthone- $\mathrm{A}$, which the highest concentration of xathones is possessed by MRE with maturity level 6.

\section{Electron spin resonance analysis}

Based on the ESR of MRE in different maturity levels (Figure $2 \mathrm{a}$ and $2 \mathrm{~b}$ ), MRE with maturity level 4, 5 and 6 have higher decreasing of g value compared to DPPH free radical.

\section{Quantitative analysis of Liquid chromatography mass spectrometry} (LC-MS/MS) profiling

The LC-MS/MS analysis (Table 2) shows that the high $\gamma$-mangostin, garcinone-E, gartanin, smeathxanthone-A concentrations are occupied by mangosteen rind with maturity level 6 respectively 66.13, 209.51,

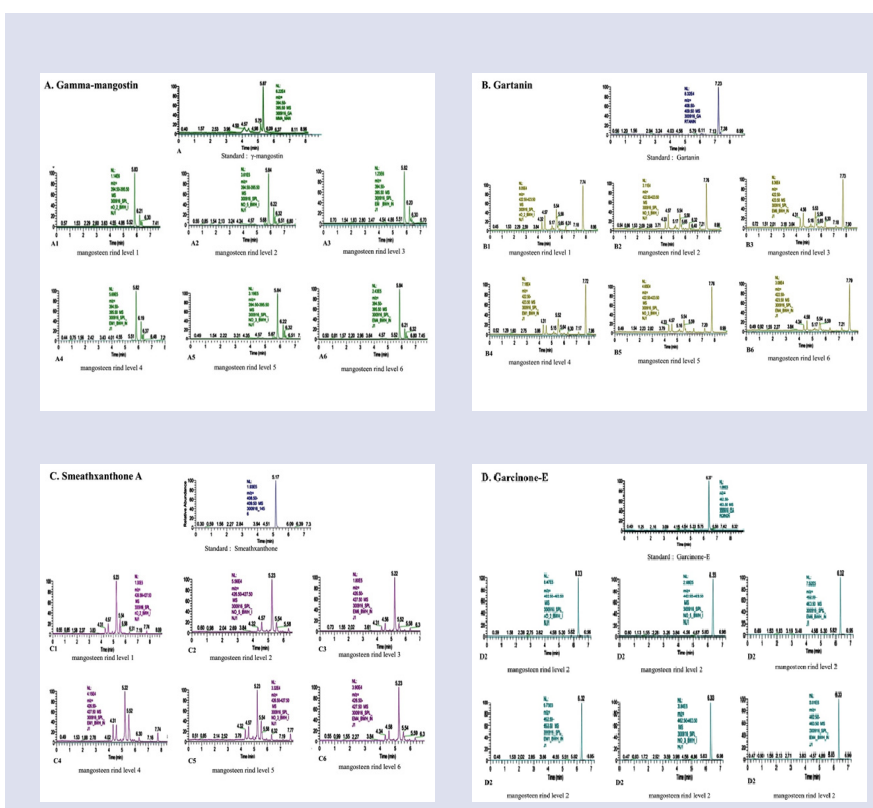

Figure 1: Chromatogram of LC-MS/MS Analysis of four standard compounds and six maturity level of mangosteen rind.

A. Standard: $\gamma$-mangostin, (A1) mangosteen rind level 1, (A2) mangosteen rind level 2, (A3) mangosteen rind level 3, (A4) mangosteen rind level 4, (A5) mangosteen rind level 5, (A6) mangosteen rind level 6

B. Standard: Gartanin, (B1) mangosteen rind level 1, (B2) mangosteen rind level 2, (B3) mangosteen rind level 3, (B4) mangosteen rind level 4, (B5) mangosteen rind level 5, (B6) mangosteen rind level 6

C. Standard: Smeathxanthone, (C1) mangosteen rind level 1, (C2) mangosteen rind level 2, (C3) mangosteen rind level 3, (C4) mangosteen rind level 4, (C5) mangosteen rind level 5, (C6) mangosteen rind level 6

D. Standard: Garcinone-E, (D1) mangosteen rind level 1, (D2) mangosteen rind level 2, (D3) mangosteen rind level 3, (D4) mangosteen rind level 4, (D5) mangosteen rind level 5, (D6) mangosteen rind level 6 


\section{Table 1: Level of mangosteen and its characteristic.}

Characteristics
Light greenish yellow with 5-50\% scattered pink spots, the
fruit has not mature and contains high amount of sap, the
fruit is quite hard to be separated from the skin flesh.

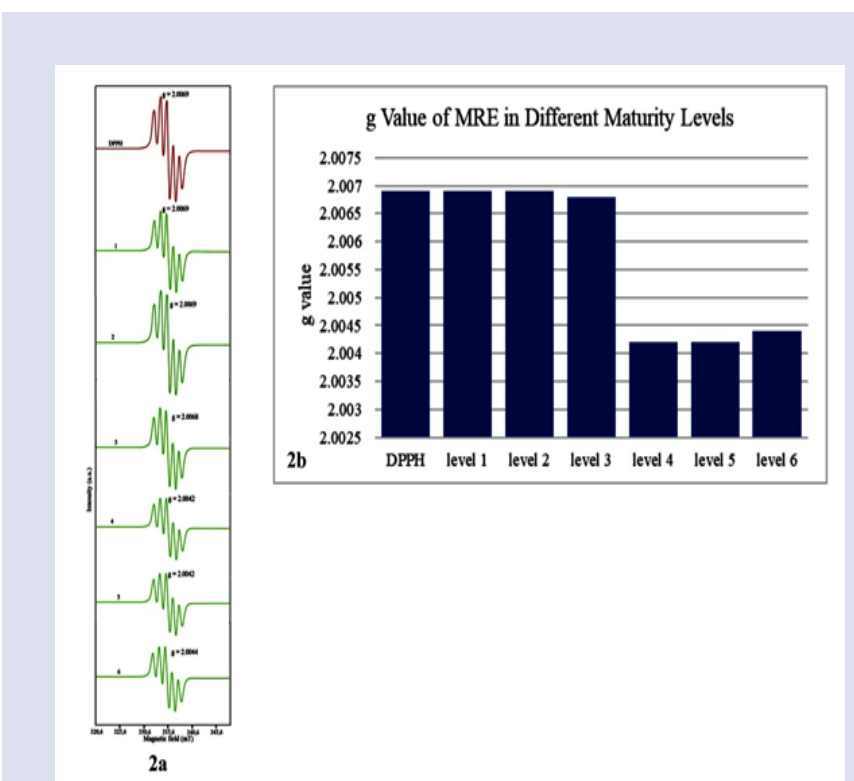

Figure 2: Result of Electron Spin Resonance (ESR) of MRE in Different Maturity Levels. (Figure 2a. Electron Spin Resonance Spectra of MRE in Different Maturity Levels; Figure 2b. g Value of MRE in Different Maturity Levels)..

${ }^{\star} \mathrm{DPPH}(2,2$-diphenyl-1-picrylhydrazyl) was used as standard for free radical compared to DPPH plus six different maturity levels of mangosteen rind extract.

Table 2: The Mean and Deviation Standard of Xanthones Concentration in MRE Based on LC-MS/MS Analysis.

\begin{tabular}{|c|c|c|c|c|c|c|c|}
\hline \multirow[t]{2}{*}{$\begin{array}{l}\text { Compounds } \\
\text { Marker }\end{array}$} & \multirow[t]{2}{*}{ Result } & \multicolumn{6}{|c|}{$\begin{array}{l}\text { Mangosteen Rind } \\
\text { (Maturity Level) }\end{array}$} \\
\hline & & 1 & 2 & 3 & 4 & 5 & 6 \\
\hline$\gamma$-mangostin & Calculated-Content $(\mu \mathrm{g} / \mathrm{mg})$ & $0.94 \pm 0.00$ & $3.20 \pm 0.01$ & $18.18 \pm 0.95$ & $18.97 \pm 0.11$ & $48.42 \pm 2.67$ & $66.13 \pm 1.59$ \\
\hline Garcinone-E & Calculated-Content $(\mu \mathrm{g} / \mathrm{mg})$ & $78.53 \pm 3.5$ & $89.43 \pm 0.38$ & $78.17 \pm 2.2$ & $139.16 \pm 1.2$ & $115.50 \pm 3.2$ & $209.51 \pm 2.7$ \\
\hline Gartanin & Calculated-Content $(\mu \mathrm{g} / \mathrm{mg})$ & $22.44 \pm 0.06$ & $23.26 \pm 0.05$ & $30.91 \pm 0.04$ & $43.10 \pm 1.47$ & $29.49 \pm 0.57$ & $51.10 \pm 1.10$ \\
\hline Smeathxanthone-A & Calculated-Content $(\mu \mathrm{g} / \mathrm{mg})$ & $1.49 \pm 0.01$ & $1.58 \pm 0.24$ & $2.48 \pm 0.23$ & $2.36 \pm 0.06$ & $4.42 \pm 0.07$ & $5.97 \pm 0.18$ \\
\hline
\end{tabular}

*The data including area, xanthones content based on calculating $(\mu \mathrm{g} / \mathrm{mg})$. The experiment was done in duplicate. The xanthones concentration in MRE with marker $\gamma$-mangostin, GarcinoneE, Gartanin, Smeathxanthone-A

51.10, $5.97 \mu \mathrm{g} / \mathrm{mg}$. The different maturity level of MRE resulted different xanthones concentration.

\section{DISCUSSION}

This present study determined the six different levels of maturity of mangosteen rind using LC-MS/MS. The maturity level of the fruit was classified by pericarp color into six level: yellowish white or yellowish white with light green (level 0), light greenish yellow with $5-50 \%$ scattered pink spots (level 1), light greenish yellow with $51-100 \%$ scattered pink spots (level 2), spots not as distinct as in level 2 or reddish pink (level 3), red to reddish purple (level 4), dark purple (level 5) and purple black (level 6). ${ }^{16}$ According to Pothihirat, ${ }^{2}$ total bioactive compound contents and antioxidant activity were found to be different in various maturation levels of mangosteen fruit. ${ }^{2}$ The LC-MS/MS analysis method can be used in quantitative determination of compounds from natural sources. ${ }^{8,20}$ Different maturity level of MRE resulted in the different xanthones concentration, this result was consistent with previous research that the ripeness reduced fruit weight due to water loss. During maturation and ripening, the disappearance of the chlorophyll and the development of carotenoid induced the change color of fruit into yellow, orange, red or purple color. ${ }^{23}$ During the fruit ripening process, physiochemical properties will change, which generally consists of changing the colors, the composition of the cell wall (texture), starch, protein, phenol derivative compounds and organic acids content. ${ }^{24}$

This result was not validated with previous research that xanthone content of mangosteen rind is constant relatively during ripeness. Various fruit level can be used as xanthone source, both mature and immature fruit. ${ }^{25}$ The xanthones content was not different in young and ripe fruit of 
mangosteen rind extract. ${ }^{25}$ The major changes in ripeness fruit are changes in color, total soluble solid, total titratable acid and content of bioactive (anthocyanin and carotenoids). ${ }^{26}$

Mangosteen rind contained $\gamma$-mangostin, gartanin, smeathxanthone-A and garcinone $\mathrm{E}$ were identified in each sample. This study has similar result with previous research which showed that mangosteen is a source of mangostin, tannin, chrysanthemin, garcinone, gartanin, vitamin B1, $\mathrm{B} 2$ and vitamin $\mathrm{C}$, xanthones such as $\alpha$-and $\beta$ mangostin, ${ }^{27,7}$ mangosteen rind contained $\alpha$-mangostin 105 ppm, $\gamma$-mangostin 7.20 ppm, $9.92 \mathrm{ppm}$ Garcinone-C and Garcinone-D 3.50 ppm. ${ }^{4}$ The mangosteen has been noted to be an abundant source of polyphenols which known as xanthones. The diverse structure and chemical properties of xanthones have been reported to have a variety of health promoting agents including antiinflammatory, antioxidant and anticancer activity. ${ }^{28}$

The highest xanthones concentration including $\gamma$-mangostin, garcinone $\mathrm{E}$, gartanin, smeathxanthone-A (Table 1) have shown by the MRE with maturity level 6 . This result was not consistent with previous research that the older mangosteen fruit has larger fruit size. The fruit size and its maturity influenced the vitamin $\mathrm{C}$ content and bioactive compounds which the larger fruits had the higher content of vitamin C. ${ }^{12}$ This result was consistent with previous research that showed mangosteen rind color indicates antioxidant activity relating to the concentration of phenolics and flavonoids. ${ }^{29}$ The dark purple pericarp of mangosteen contains a variety of bioactive secondary metabolites such as anthocyanin and xanthone. ${ }^{30,31} \mathrm{MRE}$ with maturity level 6 contained the highest content of $\gamma$-mangostin, gartanin, smeathxanthone $\mathrm{A}$ and garcinone $\mathrm{E}$. This result was not consistent with previous research which obtained the young of MRE contained higher contents of phenolic than the mature one, significantly. ${ }^{2}$ This research showed that the highest xanthones concentration was in the mangosten rind with maturity level 6 . Therefore, it was estimated that xanthone content in mangosteen was linear with the increasing level of maturity.

Electron Spin Resonance (ESR) spectroscopy is known by its strong capability to determine antioxidative compounds. ESR spectroscopy is a unique method to detect free radicals and other substances which have no effect on the registered signal, it reflects the actual antioxidative properties of the studied material. ${ }^{22}$ Antioxidant activity was determined using ESR spectrometer by measuring the absorption of electromagnetic radiation. DPPH (2,2-diphenyl-1-picrylhydrazyl) was used as the standard or stable free radical compared to DPPH plus six different maturity levels of mangosteen rind extract. The absorption of electromagnetic radiation of each maturity level of mangosteen rind extract are showed in Figure 2.

Each maturity level has different g value compared to DPPH as standard free radical, with the g value was 2.0069. The difference of $g$ value indicates different type of free radical. ${ }^{15}$ Type of free radical MRE level 1 and MRE level 2 were not different from DPPH standard. Further analysis method should be done to determine the exact type of free radical, for instance, using Nuclear Magnetic Resonance (NMR). In addition, antioxidant status of the samples can be effectively monitored through the reduction of stable free radicals added to the sample. ${ }^{15}$

Dramatic changes in ESR signal are found in the presence of MRE. It was observed the proportional decrease of DPPH signal heights after addition of different samples. ${ }^{32}$ Some maturity levels of MRE had decreasing g value compared to DPPH radical. The decrease $g$ value indicates the decrease intensity of free radical. The higher decreasing magnetic field was MRE level 4, 5 and 6. It showed that the addition of MRE 4, 5 and 6 into DPPH free radical were strongly able to lower the intensity of free radical. MRE level 4, 5 and 6 have the higher antioxidant to scavenge DPPH free radical.
The DPPH radical scavenging activity measures the antioxidant ability for donating hydrogen atom to capture the DPPH radical (DPPH). ${ }^{11,4,20}$ The DPPH scavenging activity is influenced by the structure, the position and degree of hydroxylation on the ring structure as well as the electron and hydrogen donating activity of polyphenols, present in mangosteen rind extract. ${ }^{15}$

The differences between antioxidant activities among the samples are presumably affected by maturation. Concentration of phenolic compounds among different level of maturity of mangosteen had been measured by Pothihirat et al. ${ }^{2}$ The mangosteen rind has been reported to contain a variety of bioactive compounds with potential applications as therapeutic agents such as xanthones and other bioactive compounds, ${ }^{5}$ these isolated compounds have various biological effects such as antioxidant. ${ }^{33,11}$ The factors affecting antioxidant activity of MRE were the quality of mangosteen rind, environmental and technological factors affecting the antioxidants activities. ${ }^{11}$ The maturation level affecting the antioxidant activities, total bioactive compound content and antioxidant activity were found to be different in various maturation levels of mangosteen fruit. $^{2}$ The mature fruit rind had higher total flavonoid content $(4.08 \mathrm{~g}$ $\mathrm{QE} / 100 \mathrm{~g})$ than the young fruit rind $(2.91 \mathrm{~g} \mathrm{QE} / 100 \mathrm{~g})$. The higher antioxidant activity of the mature fruit rind may be resulted from the higher total flavonoid. ${ }^{11}$

\section{CONCLUSION}

Maturity level 6 of mangosteen rind has the highest total xanthones. Mangosteen rind level 4, 5 and 6 have the higher decreasing of magnetic field value and the highest DPPH free radical scavenging activity.

\section{ACKNOWLEDGEMENT}

We acknowledge the contribution of National Nuclear Power Agency Serpong Banten-Indonesia, School of Life Sciences and Technology, Bandung Institute of Technology Bandung-Indonesia, Faculty of Medicine Brawijaya University Malang-Indonesia, Faculty of Pharmacy University of Surabaya Surabaya-Indonesia and Biomolecular \& Biomedical Research Centre, Aretha Medika Utama Bandung-Indonesia.

\section{CONFLICT OF INTEREST}

The authors declare no conflict of interest.

\section{ABREVIATIONS}

DPPH: 2,2-diphenyl-1-picrylhydrazyl; EPR: Electron paramagnetic resonance; ESI: Electrospray Ionization; ESR: Electron spin resonance; FMW: Field modulation width; LC-MS/MS: Liquid Chromatography Mass Spectrometry; MRE: Mangosteen rind extract; NMR: Nuclear magnetic resonance.

\section{REFERENCES}

1. Fitzmaurice SD, Sivamani RK, Isseroff RR. Antioxidant therapies for wound healing: A clinical guide to currently commercially available products. Skin Pharmacol Physiol. 2011;24(3):113-26.

2. Pothitirat W, Chomnawang MT, Supabphol R, Gritsanapan W. Comparison of bioactive compounds content, free radical scavenging and anti-acne inducing bacteria activities of extracts from the mangosteen fruit rind at two stages of maturity. Fitoter. 2007;80(7):442-7.

3. Hajhashemi V, Vaseghi G, Pourfarzam M, Abdollahi A. Are antioxidants helpful for disease prevention?. Res Pharm Sci. 2010;5(1):1-8.

4. Widowati W, Fauziah N, Herdiman H, Afni M, Afifah E, Kusuma HSW, et al. Antioxidant and anti aging assays of Oryza sativa extracts, vanillin and coumaric acid. J Nat Remed. 2016;16(3):88-99.

5. Zarena AS, Udaya SK. Screening of xanthone from mangosteen (Garcinia mangostana L.) rinds and their effect on cytochrome $c$ reductase and phosphomolybdenum activity. J Nat Prod. 2009;2(1):23-30.

6. Widowati W, Darsono L, Suherman J, Yelliantty Y, Maesaroh M. High Perfor- 
mance Liquid Chromatography (HPLC) analysis, antioxidant, antiaggregation of mangosteen peel extract (Garcinia mangostana L.). Int J Biosci Biochem Bioinform. 2014;4(6):458.

7. Abuzaid AS, Iskandar EY, Kurniati NF, Adnyana IK. Preventive effect on obesity of mangosteen (Garcinia mangostana L.) pericarp ethanolic extract by reduction of fatty acid synthase level in monosodium glutamate and high-calorie diet-induced male wistar rats. Asian J Pharm Clin Res. 2016;9(3);257-60.

8. Walker ED. HPLC analysis of selected xanthones in mangosteen fruit. J Sep Sci. 2007;30(1):1229-34.

9. Gutierrez-Orozco F, Failla ML. Biological activities and bioavailability of mangosteen xanthones: A critical review of the current evidence. Nutrients. 2013;5(8):3163-83.

10. Widowati W, Darsono L, Suherman J, Fauziah N, Maesaroh M, Erawijantari PP. Anti-inflammatory effect of mangosteen (Garcinia mangostana L.) rind extract and its compounds in LPS-induced RAW 264.7 cells. Nat Prod Sci. 2016;22(3):147-53.

11. Suttirak W, Manurakchinakom S. In vitro antioxidant properties of mangosteen peel extract. J Food Sci Technol. 2012;51(12):3546-58.

12. Kurniawati A, Poerwanto R, Sobir S, Efendi D, Cahyana H. Evaluation of fruit characters, xanthones content and antioxidant properties of various qualities of mangosteens (Garcinia mangostana L.). J Agron Indonesia. 2010;38(3):232-7.

13. Polovka M, Brezova $V$, Stasko A. Antioxidant properties of tea investigated by EPR spectroscopy. Biophys Chem. 2003;106(1):39-56.

14. Masaichi-Chang IL. Assessment of oxidative stress and antioxidant property using Electron spin resonance (ESR) spectroscopy. J Clin Biochem Nutr. 2013;52(1):1-8

15. Polovka M. EPR spectroscopy: A tool to characterize stability and antioxidant properties of foods. J Food Nutr Res. 2006;45(1):1-11.

16. Palapol Y, Ketsa S, Stevenson D, Cooney JM, Allan AC, Ferguson IB. Colour development and quality of mangosteen (Garcinia mangostana L.) fruit during ripening and after harvest. Postharvest Biol Technol. 2009;51(1):349-53.

17. Hadriyono KRP. Karakter kulit manggis, kadar polifenol dan potensi antioksidan kulit manggis (Garcinia mangostana, Linn) pada berbagai umur buah dan setelah buat dipanen. Thesis Departemen Agronomi dan Hortikultura. Bogor. 2011.

18. Parabasari I, Utama NA, Hasanah NAU, Riyadi S, Hariadi TK. Non destructive method for maturity index determination of Garcinia mangostana L. using image processing technology. Int Soc Hortic Sci. 2016;8(3):1.

19. Lucini L, Pellizzoni M, Baffi C, Molinari GP. Rapid determination of Iycopene and $\beta$-carotene in tomato by liquid chromatography/electrospray tandem mass spectrometry. J Sci Food Agric. 2012;92(6):1297-303.
20. Widowati W, Rani AP, Hamzah RA, Arumwardana S, Afifah E, Kusuma HSW, et al. Antioxidant and antiaging assays of Hibiscus sabdariffa extract and its compounds. Nat Prod Sci. 2017;23(3):192-200.

21. Kuzmanova SV, Blaqovic B, Valic S. Electron spin resonance measurement of radical scavenging activity of Aronia melanocarpa fruit juice. Pharmacogn Mag 2012;8(30):171-4.

22. Bartoszek M, Polak J. A comparison of antioxidative capacities of fruit juices, drinks and nectars, as determined by EPR and UV-vis spectroscopies. Spectrochim Acta A Mol Biomol Spectrosc. 2016;153(1):546-9.

23. Anabesa MS. Maturity indices mangosteen. Philip J Crop Sci. 1992;17(3):115-8

24. Eskin NAM. Biochemistry of food. Academic Press. Inc. $2^{\text {nd }}$ Edition San Diego, California. 1990.

25. Kurniawati A, Poerwanto R, Sobir S, Efendi D, Cahyana H. Character, xanthone content and antioxidant properties of mangosteen fruit's hull (Garcinia mangostana L.) at several fruit growth stadia. J Agron Indonesia. 2011;39(3):188-92.

26. D’ız-Mula HM, Zapata PJ, Guille'n F, Castillo S, Mart'inez-Romero D, Valero $\mathrm{D}$, et al. Changes in physicochemical and nutritive parameters and bioactive compounds during development and on tree ripening of eight plum cultivars: a comparative study. J Sci Food Agric. 2008;88(14):2499-507.

27. Jindarat S. Xanthones from mangosteen (Garcinia mangostana): multi-targeting pharmacological properties. J Med Assoc Thai. 2014;97(Suppl. 2):S196-201.

28. Li G, Thomas S, Johnson JJ. Polyphenols from the mangosteen (Garcinia mangostana) fruit for breast and prostate cancer. Fronties Pharmcolog. 2013;4(80):1-4.

29. Lourith N, Kanlayavattanakul M. Biological activity and stability of mangosteen as a potential natural color. Biosci Biotechnol Biochem. 2011;75(11):2257-9.

30. Fu C, Loo AE, Chia FP, Huang D. Oligomeric proanthocyanidins from mangosteen pericarps. J Agric Food Chem. 2007:55(19):7689-94.

31. Ji X, Avula B, Khan IA. Quantitative and qualitative determination of six xanthones in Garcinia mangostana L. by LC-PDA and LC-ESI-MS. J Pharmaceut Biomed Anal. 2007;43(4):1270-6

32. Yoshimura $Y$, Inomata $T$, Nakazawa $H$, Kubo $H$, Yamaguchi $F$, Ariga T. Evaluation of free radical scavenging activities of antioxidants with an $\mathrm{H}_{2} \mathrm{O}_{2} / \mathrm{NaOH} / \mathrm{DMSO}$ system by electron spin resonance. J Agric Food Chem. 1999;47(11):4653-6.

33. Jung HA, Su BN, Keller WJ, Mehta RG, Kinghorn AD. Antioxidant xanthones from the pericarp of Garcinia mangostana (Mangosteen). J Agri Food Chem. $2006 ; 54(6): 2077-82$

\section{GRAPHICAL ABSTRACT}
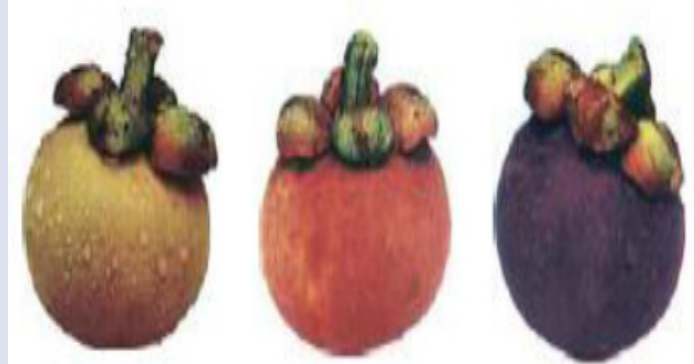

ABOUT AUTHORS
Marisca Evalina Gondokesumo was born at Surabaya, 7th 1988. She studied at Biomedical Sciences Doctoral Program Faculty of Medicine, Brawijaya University, Malang city, East Java, Indonesia. She is woking as a lecturer in Faculty of Pharmacy, University of Surabaya (UBAYA) East Java, Indonesia. Her lastest publication was "Microstructural characterization of the Garcinia mangostana fruit at Different Maturity Level." Her lastest research was about Antioxidant Activity Analysis of Six Different Maturity Levels of Mangosteen Rind Extract (Garcinia mangostana Linn.) using Electrone spin resonance (ESR).

Cite this article: Gondokesumo ME, Pardjianto B, Sumitro SB, Widowati W, Handono K. Xanthones Analysis and Antioxidant Activity Analysis (Applying ESR) of Six Different Maturity Levels of Mangosteen Rind Extract (Garcinia mangostana Linn.). Pharmacog J. 2019;11(2):369-73. 